\title{
Characterization of ligand response properties of the CRP protein from Pseudomonas putida
}

\author{
JIANG Feng, TIAN ZheXian \& WANG YiPing* \\ State Key Laboratory of Protein and Plant Gene Research, College of Life Sciences, Peking University, Beijing 100871, China
}

Received April 18, 2012; accepted June 18, 2012; published online July 16, 2012

\begin{abstract}
cAMP receptor protein (CRP) plays profound roles in many bacteria as a global regulator. In Escherichia coli, $\mathrm{CRP}_{\text {E. coli }}$ modulates the expression of many operons involved in carbon catabolism, in response to the fluctuation of intracellular cAMP level caused by carbon catabolism. A crp homologue gene has been identified in the genome of Pseudomonas putida, however, little is known about its cellular function. In this work, we investigated ligand response properties of this CRP protein $\left(\mathrm{CRP}_{P \text {. putida }}\right)$. The results showed that in the presence of exogenous cAMP or cGMP, $\mathrm{CRP}_{P \text {. putida }}$ can activate the lac promoter in E. coli cya crp mutant. In vitro isothermal titration calorimetry (ITC) assays indicated that $\mathrm{CRP}_{P \text {. putida }}$ could bind cAMP as well as cGMP. Its affinity to cAMP is much higher than $\mathrm{CRP}_{E \text {. coli }}$. Sequence alignment of the CRP proteins suggested that the Thr132 of $\mathrm{CRP}_{P \text {. putida }}$ (analogous to Ser128 of $\mathrm{CRP}_{E \text {. coli }}$ ) could be the key determinant for all ligand responsive properties observed above. When Thr132 of $\mathrm{CRP}_{P \text {. putida }}$ is mutated to Serine, two phenomena were observed: (i) its affinity to cAMP or cGMP was reduced to a level similar to $\mathrm{CRP}_{\text {E. coli }}$; (ii) its transcriptional activation activity on E. coli lac promoter was diminished. The potential physiological implications of these ligand binding properties are discussed.
\end{abstract}

Pseudomonas putida, CRP, cAMP, high affinity, cGMP

Citation: Jiang F, Tian Z X, Wang Y P. Characterization of ligand response properties of the CRP protein from Pseudomonas putida. Chin Sci Bull, 2012, 57: 3878-3885, doi: 10.1007/s11434-012-5360-3

cAMP receptor protein (CRP), a key member of CRP-FNR family, is widely distributed in prokaryotes, acting as a global regulator [1]. CRP proteins exert regulatory effect in the process of carbon metabolism, nitrogen assimilation, photosynthesis and virulence factor regulation [2-4]. The CRP protein of Escherichia coli $\left(\mathrm{CRP}_{\text {E. coli }}\right)$ is probably the best-characterized protein in the CRP-FNR family. It regulates the transcription of more than 200 genes in E. coli [5]. Upon cAMP binding, $\mathrm{CRP}_{E \text {. coli }}$ undergoes certain conformational changes, which in turn facilitate recognition of specific DNA target site. When it is the sole activator, DNA target site bound $\mathrm{CRP}_{E \text {. coli }}$ interacts with RNA polymerase holoenzyme (RNAP), and recruits RNAP to the target promoter, which in turn initiates gene transcription [6]. $\mathrm{CRP}_{\text {E. coli }}$ functions as a dimer of approximately $47 \mathrm{kD}$. Each monomer can bind two molecules of cAMP [7]. It consists of 209

*Corresponding author (email: wangyp@pku.edu.cn) amino acid residues and two major structural domains. The $\mathrm{N}$-terminal domain (residues 1-133) contains a cAMPbinding hydrophobic pocket and the C-terminal domain (residues 139-209) contains the DNA recognition motif [8]. The consensus sequence of $\mathrm{CRP}_{E}$. coli binding site is AAATGTGAN6TCACATTT, a 22-base motif containing an inverted repeat [9].

In E. coli, as the allosteric ligand of CRP protein, cAMP is synthesized by the adenylate cyclase encoded by cyaA. Intracellular cAMP concentration is tightly controlled and fluctuates significantly in response to quality change of carbon source. This control is achieved by the phosphoenolpyruvate-dependent phosphotransferase system (PTS). When cells are grown on the PTS carbon source such as glucose, cAMP level stays low and $\mathrm{CRP}_{E \text {. coli }}$ exerts little activity. Intracellular cAMP level increases dramatically when cells are grown on the non-PTS carbohydrates, and subsequently the activity of $\mathrm{CRP}_{E \text {. coli }}$ is triggered by cAMP 
binding. Genes related to carbohydrate metabolism such as lactose, galactose and arabinose are activated by $\mathrm{CRP}_{E \text {. coli }}{ }^{-}$ cAMP [10]. Meanwhile, key operons like $g \ln A L G$ and $g \ln H P Q$ which encode crucial proteins in nitrogen acquisition and ammonium assimilation, are proven to be regulated by the complex as well $[4,11]$. High through-put genomic analysis confirmed that the $\mathrm{CRP}_{E}$. coli -cAMP complex participates mostly in the regulation of genes which involved in the transport and metabolism of carbon and nitrogen source [5]. Although CRP E. coli can bind cGMP, no evidences show that cGMP-binding could induce $\mathrm{CRP}_{\text {E. coli }}$ 's conformational change required for DNA binding and transcriptional regulation [12].

The genus Pseudomonas comprises a group of strains that have profound environmental or pathogenic relevance. Pseudomonas putida is a widely studied pseudomonad for its potential application in bioremediation and biodegradation. Its genome encodes a CRP ortholog (PP_0424) that shares $62 \%$ identity and $80 \%$ similarity with the E. coli counterpart [13]. These two proteins share the similar cAMP binding pocket for ligand recognition and helixturn-helix (HTH) motif for DNA binding. However, their physiological roles seem to be quite different [14]. In $P$. putida strain KT2440 (strain mt-2 deprived of mega- plasmid pWW0), $\mathrm{CRP}_{P \text {. putida }}$ plays a role in the utilization of several dipeptide as nutrients and has little influence on the carbon source metabolism [14]. In $P$. putida strain DOT-T1E, a crp mutant was unable to grow in the medium with ammonium as sole nitrogen source [15]. Therefore, the physiological role of $\mathrm{CRP}_{P \text {. putida }}$ is probably related to the nitrogen metabolism rather than the carbon metabolism. Intracellular cAMP in $P$. putida is produced by the enzyme encoded by the cyaA ortholog (PP_5222, CyaA $\left.{ }_{P \text {. putida }}\right)$ [14]. The mutual dependence of $\mathrm{CyaA}_{P \text {. putida }}$ and $\mathrm{CRP}_{P \text {. putida }}$ for full regulatory function was established recently [14]. Following recent discovery of the existence of cGMP in bacteria [16], evidences have elucidated that members of CRP family protein respond to cGMP or c-di-GMP [17-19], suggesting cyclic nucleotide other than cAMP might have important roles in binding CRP homologues.

In this study, we characterized the signal responsive properties of $\mathrm{CRP}_{P}$. putida, and significant deviation was ovserved compared to $\mathrm{CRP}_{\text {E. coli }}$. Further determination of key residues for signal responsive properties was also carried out.

\section{Materials and methods}

\subsection{Strains, plasmids and media}

The bacterial strains and plasmids used in this work are listed in Table 1. The crp cyaA double mutant strains, BD7000 and BD8000, were constructed from E. coli MG1655 or BL21(DE3) respectively by P1 transduction. The donor strains (JW3778-3 and JW5702-4) were purchased from the Coli Genetic Stock Center. Briefly, lysates were first generated by growing P1vir phage on the JW3778-3 and JW5702-4. The resulting lysate of JW3778-3 was used to incubate with MG1655 or BL21(DE3) to construct the MG1655 $\triangle c y a A$ or BL21(DE3) $\triangle c y a A$ mutant, then the lysate of JW5702-4 was applied subsequently to MG1655 $\triangle c y a A$ or BL21(DE3) $\triangle c y a A$ strain to get the final BD7000 or BD8000.

For routine growth, bacteria were grown at $37^{\circ} \mathrm{C}$ (for $E$. coli) or $30^{\circ} \mathrm{C}$ (for P. putida) in Luria-Bertani (LB) broth. For $\beta$-galactosidase assay, bacteria were grown in minimal M9 medium with $0.4 \%$ glucose as carbon source and 1 mmol L ${ }^{-1}$ IPTG was added for expression of the CRP proteins. For the protein preparation, strains were grown in M9 medium supplemented with $1 \%$ glucose and $0.4 \%$ casamino acid (Difco) at $30^{\circ} \mathrm{C}$.

\subsection{Recombinant DNA techniques}

Preparation of chromosomal and plasmid DNA, PCR amplification, restriction enzyme digestions, ligations and transformations were performed as described [23]. The site-directed mutagenesis of CRP was done by using the QuickChange ${ }^{\circledR}$ Site-Directed Mutagenesis Kit (Stratagene). In brief, two complementary primers (listed below) containing the desired mutation were applied for PCR amplification using pKU9401 as template. Subsequently, the PCR mixture was digested with $D p n I$ and transformed into TOP10 competent cell (Invitrogen). The resulting plasmids containing the DNA fragments with specific mutation were verified by sequencing. The primers used are: p1, 5'-CGCCTGCGCAACACTTCACGCAAGGTTGGCGATT-3'; p2: 5'AATCGCCAACCTTGCGTGAAGTGTTGCGCAGGCG-3' (for $\mathrm{CRP}_{\text {P. putida }} \mathrm{T} 132 \mathrm{~S}$ construct); p3: 5'-GAGCTAGGCCTGTTCGAGGATGGCCAGCAGCGCAGTGCCTGG-3'; p4: 5'-CCAGGCACTGCGCTGCTGGCCATCCTCGAACAGGCCTAGCTC-3' (for $\mathrm{CRP}_{P \text {. putida }}$ Iex construct).

\subsection{Enzyme assays}

The $\beta$-galactosidase activity assay was carried out as described by Miller [24].

\subsection{Protein, antibody preparation and Western blot}

To purify CRP and the mutant proteins, $c r p$ and derivative mutant genes were PCR amplified and cloned into the expression vector pET28a (Novagen) between Nde I and Hind III sites. Confirmed by sequencing, the resulting plasmids (pKU9800, pKU9801, pKU9802 and pKU9810) were introduced into expression strain BD8000. To express the protein, the strain was pre-grown overnight in M9 liquid medium. The overnight culture was diluted $1: 100$ into fresh M9 medium and grown at $30^{\circ} \mathrm{C}$. At $A_{600}$ of 0.5 , IPTG was added to a final concentration of $0.5 \mathrm{mmol} \mathrm{L} \mathrm{L}^{-1}$. After $6 \mathrm{~h}$ induction, cells were collected by centrifugation. The pellet 
Table 1 Bacterial strains and plasmids

\begin{tabular}{|c|c|c|}
\hline Strains or plasmids & Characteristics & Source \\
\hline \multicolumn{3}{|l|}{ Strains } \\
\hline \multicolumn{3}{|l|}{ Escherichia coli } \\
\hline MG1655 & $\mathrm{F}^{-} l a m b d a^{-} i l v G-r f b-50 r p h-1$ & Lab stock \\
\hline TOP10 & $\begin{array}{l}\mathrm{F}^{-} \text {mcrA } \Delta(m r r-h s d \mathrm{RMS}-m c r \mathrm{BC}) \varphi 80 l a c \mathrm{Z} \Delta \mathrm{M} 15 \Delta \text { lacX74 nup } \mathrm{G} \text { recA1 araD139 } \Delta \text { (ara-leu)7697 galE15 } \\
\text { galK16 rpsL(Str) endA1 }\end{array}$ & Invitrogen \\
\hline BL21(DE3) & $\mathrm{F}^{-}$omp $\mathrm{T} h s d \mathrm{SB}\left(\mathrm{rB}^{-} \mathrm{mB}^{-}\right)$gal dcm $(\mathrm{DE} 3)$ & Novagen \\
\hline JW3778-3 & 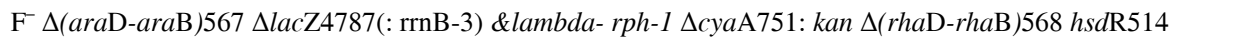 & [20] \\
\hline JW5702-4 & 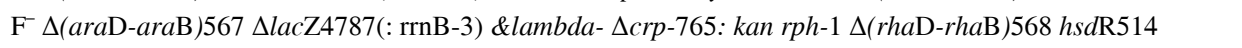 & [20] \\
\hline BD7000 & MG1655 $\Delta c r p \triangle c y a A$ & This work \\
\hline BD8000 & BL21(DE3) $\Delta c r p \Delta c y a A$ & This work \\
\hline \multicolumn{3}{|l|}{ Pseudomonas putida } \\
\hline$m t-2$ & Wild type & [21] \\
\hline \multicolumn{3}{|l|}{ Plasmids } \\
\hline pVTRA' & pSC101 derivative, $l a c l^{\mathrm{q}}-\mathrm{Ptac}$ expression vector, $\mathrm{Cm}^{\mathrm{r}}$ & [22] \\
\hline pET28a & Histag overexpression vector, $\operatorname{Kan}^{\mathrm{r}}$ & Novagen \\
\hline pBluescript-SK & ColE1, lac Z', Ap ${ }^{\mathrm{r}}$ & Stratagene \\
\hline pKU9401 & pBluescript containing $P$. putida crp gene, $\mathrm{Ap}^{\mathrm{r}}$ & This work \\
\hline pKU9500 & pVTRA' derivative encoding $\mathrm{CRP}_{\text {E. coli }}, \mathrm{Cm}^{\mathrm{r}}$ & This work \\
\hline pKU9600 & pVTRA' derivative encoding $\mathrm{CRP}_{P \text {. putida }}, \mathrm{Cm}^{\mathrm{r}}$ & This work \\
\hline pKU9601 & pVTRA' derivative encoding $\mathrm{CRP}_{P \text {. putida }} \mathrm{T} 132 \mathrm{~S}, \mathrm{Cm}^{\mathrm{r}}$ & This work \\
\hline pKU9800 & pET28a derivative expressing His-tagged $\mathrm{CRP}_{P . \text { putida }}, \operatorname{Kan}^{\mathrm{r}}$ & This work \\
\hline pKU9801 & pET28a derivative expressing His-tagged $\mathrm{CRP}_{P \text {. putida }} \mathrm{T} 132 \mathrm{~S}, \mathrm{Kan}^{\mathrm{r}}$ & This work \\
\hline pKU9802 & $\begin{array}{l}\text { pET28a derivative expressing His-tagged } \mathrm{CRP}_{P . \text { putida }} \text { Iex (the three additional residues in cAMP binding } \\
\text { pocket were deleted) } \operatorname{Kan}^{\mathrm{r}}\end{array}$ & This work \\
\hline pKU9810 & pET28a derivative expressing His-tagged $\mathrm{CRP}_{E \text {. coli }}, \operatorname{Kan}^{\mathrm{r}}$ & This work \\
\hline
\end{tabular}

was resuspended in buffer A $\left(50 \mathrm{mmol} \mathrm{L}^{-1}\right.$ Tris, $\mathrm{pH} 7.4,500$ mmol L ${ }^{-1} \mathrm{NaCl}, 20 \mathrm{mmol} \mathrm{L}{ }^{-1}$ imidazole, $\left.1 \mathrm{mmol} \mathrm{L}{ }^{-1} \mathrm{DTT}\right)$ and disrupted by sonication (approx. $200 \mathrm{~W}$ for $5 \mathrm{~min}$ on ice of $10 \mathrm{~s} \mathrm{ON}$ and $10 \mathrm{~s}$ OFF mode). Cell debris was removed by centrifugation and the supernatant was passed through a HisTrap Nickel affinity column (GE Healthcare). After washing with buffer A, the proteins were eluted by buffer A supplemented with $400 \mathrm{mmol} \mathrm{L}^{-1}$ imidazole. The eluted fractions were then applied to a Superdex 75 gel filtration column (GE Healthcare). Protein purity was verified by SDS-PAGE followed by Coomassie blue staining. The purification procedures of $\mathrm{CRP}_{E \text {. coli }}, \mathrm{CRP}_{P \text {. putida }}$ and the mutants were identical as described above. The polyclonal antibody of $\mathrm{CRP}_{\text {E. coli }}$ was from lab storage. The polyclonal antibody of $\mathrm{CRP}_{P \text {. putida }}$ was obtained from the rabbit serum after $45 \mathrm{~d}$ of immunization by 4 times' purified $\mathrm{CRP}_{P \text {. putida }}$ protein injection. The secondary antibody (Goat anti Rabbit IgG HRP) was purchased from Santa Cruz Biotechnology, Inc. Western blot was performed according to the standard procedure [23]. Quantification of the intensity of protein bands was done by using Quantity One software (Bio-Rad).

\subsection{Isothermal titration calorimetry}

The protein solution was extensively dialyzed against Tris

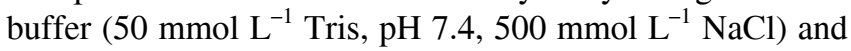
the nucleotide was solved directly in Tris buffer. The ITC measurements were carried out using a MicroCal iTC200 calorimeter (GE Healthcare) at $25^{\circ} \mathrm{C}$. In brief, 19 injections of $2 \mu \mathrm{L}$ nucleotide solutions $\left(2 \mathrm{mmol} \mathrm{L}^{-1}\right)$ were introduced at 2-min intervals into the sample cell containing $200 \mu \mathrm{L}$ CRP or the mutants $\left(0.1-0.2 \mathrm{mmol} \mathrm{L}^{-1}\right)$ with constant stirring at $1000 \mathrm{r} \mathrm{min}^{-1}$, and the heat changes accompanying the additions were recorded. The data were fitted with the one-site model (except $\mathrm{CRP}_{E \text {. coli }}$ with cAMP, which was fitted with the two-site model) to calculate the association constant $\left(K_{\mathrm{a}}\right)$ using the MicroCal ORIGIN 7.0 software.

\section{Results}

2.1 In vivo assay reveals that $\mathrm{CRP}_{P \text {. putida }}$ has versatile ligand dependency and sensitivity

In order to investigate the role of $P$. putida $\mathrm{CRP}$ as a transcription factor, plasmid expressing $\mathrm{CRP}_{P \text {. putida }}$ was introduced into the crp cya double mutant E. coli strain BD7000. In vivo activity of the chromosomal lac promoter was monitored by $\beta$-galactosidase assay, when cells were grown in M9 medium supplemented with $1 \mathrm{mmol} \mathrm{L}^{-1}$ cAMP or cGMP. As shown in Figure 1(a) and Figure 2, $\mathrm{CRP}_{P \text {. putida }}$ could activate the lac promoter in response to exogenous cAMP or cGMP in E. coli, while $\mathrm{CRP}_{E \text {. coli }}$ responded only to cAMP. Surprisingly, substantial lac promoter activity was observed in the strain expressing $\mathrm{CRP}_{P \text {. putida }}$ even under the condition without any exogenous ligand was supplied in the medium. This result indicated that $\mathrm{CRP}_{P}$. putida might 


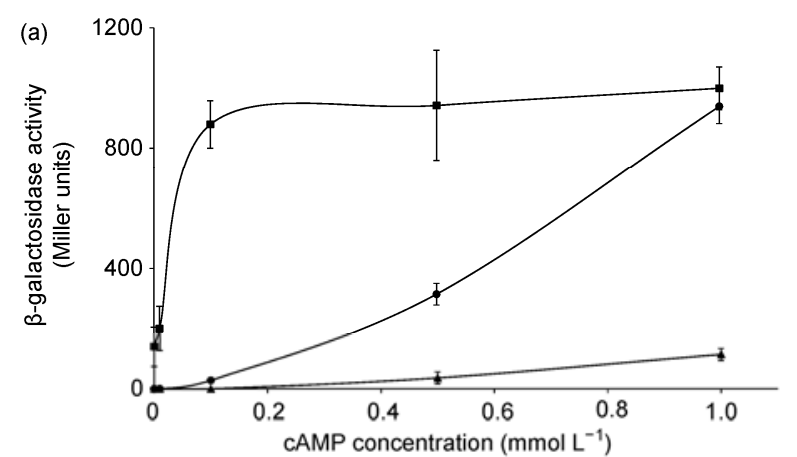

(b)

P. putida CRP

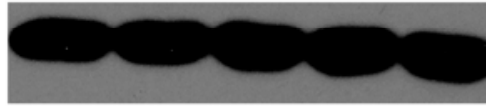

P. putida CRP T132S

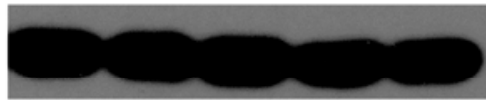

\begin{tabular}{|c|c|c|c|c|c|}
\hline & 1 & 2 & 3 & 4 & 5 \\
\hline P. putida CRP & 1.015 & 1.003 & 1.015 & 1.008 & 1.026 \\
\hline P. putida CRP T132S & 0.998 & 1.023 & 0.966 & 0.989 & 0.942 \\
\hline E. coli CRP & 1.000 & 0.991 & 0.987 & 0.990 & 0.977 \\
\hline
\end{tabular}

Figure 1 Constantly expressed CRP proteins activate lac promoter in response to titrated exogenous cAMP in E. coli. (a) E. coli strain BD7000 expressing $\mathrm{CRP}_{E \text {. coli }}, \mathrm{CRP}_{P \text {. putida }}$ or $\mathrm{CRP}_{P \text {. putida }} \mathrm{T} 132 \mathrm{~S}$ were grown in $\mathrm{M} 9$ medium supplemented with $1,0.5,0.1,0.01$ and $0 \mathrm{mmol} \mathrm{L}^{-1}$ exogenous cAMP. $\beta$-galactosidase activity was measured at the mid-log growth phase. Circle, $\mathrm{CRP}_{\text {E. coli }}$; square, $\mathrm{CRP}_{P \text {. putida }}$; triangle, $\mathrm{CRP}_{P \text {. putida }} \mathrm{T} 132 \mathrm{~S}$. (b) The upper portion shows Western blot analysis of the strains described above using $\mathrm{CRP}_{P \text {. putida }}$ or $\mathrm{CRP}_{E \text {. coli }}$ polyclonal antibody. The amounts of loading were normalized based on the concentration of the total protein. Lanes 1-5: $1,0.5,0.1,0.01,0 \mathrm{mmol} \mathrm{L}-1$ exogenous cAMP added respectively; the bottom portion illustrates the relative intensity of protein bands.

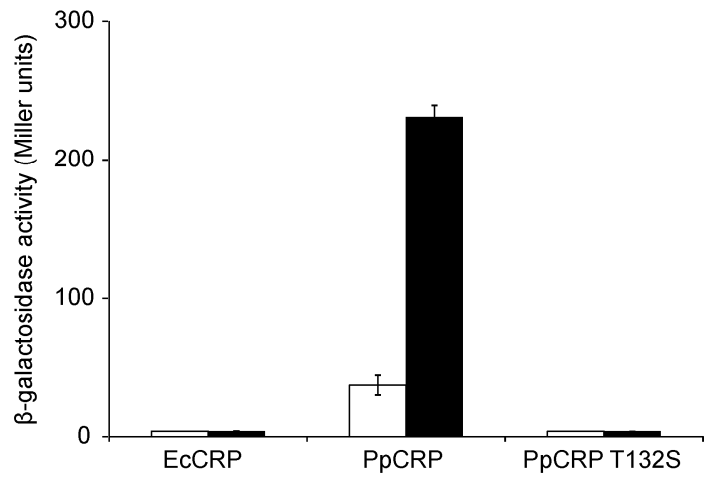

Figure 2 Exogenous cGMP triggers the activity of $\mathrm{CRP}_{P}$, putida but not $\mathrm{CRP}_{\text {E. coli }}$ or $\mathrm{CRP}_{\text {P. putida }} \mathrm{T} 132 \mathrm{~S}$ for activating lac promoter in E. coli. E. coli strain BD7000 was grown in M9 medium in the presence (black bar) or absence (white bar) of $1 \mathrm{mmol} \mathrm{L}^{-1} \mathrm{cGMP}$. EcCRP, CRP . coli $_{\text {; P PRP, CRP }}$. putida .

exert its activity independent of cAMP or cGMP.

In vivo activity assay with titrated exogenous cAMP further demonstrated that much less cAMP was required for $\mathrm{CRP}_{P \text {. putida }}$ to activate the lac promoter. In strains containing $\mathrm{CRP}_{P \text {. putida, }}$ lac promoter activity was saturated promptly in the presence of less than $0.1 \mathrm{mmol} \mathrm{L}^{-1}$ cAMP. In contrast, in strains expressing $\mathrm{CRP}_{E \text {. coli }}$, the promoter activity increased gradually and could not be maximized even in the presence of $1 \mathrm{mmol} \mathrm{L}^{-1} \mathrm{cAMP}$ (Figure 1(a)). In order to rule out the possibility of difference in intracellular protein level, Western blots was performed to examine the expressing level of proteins (Figure 1(b)). The levels of CRP proteins in every strain tested above were almost the same, suggesting that it was molecular property but not expression level that gave rise to the differences between these two proteins. Taken together, these results revealed that $\mathrm{CRP}_{P \text {. putida }}$ could act as a transcriptional regulator and possessed versatile ligand dependency and sensitivity than its $E$. coli counterpart.

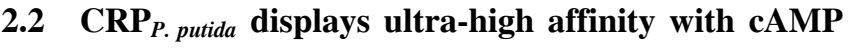 in vitro}

For the purpose of validating the in vivo results described above, in vitro ITC analysis was performed to calculate the binding parameters of CRP proteins towards cAMP and cGMP. The purified $\mathrm{CRP}_{P \text {. putida }}$ solution was mixed with either titrated cAMP or cGMP at $25^{\circ} \mathrm{C}$ (see Materials and methods), and the heat change upon binding was measured (Table 2). As shown in Figure 3(a), $\mathrm{CRP}_{P \text {. putida }}$ has a strong affinity to cAMP, with an approximately 1:1 stoichiometry and an estimated association constant $\left(K_{\mathrm{a}}\right)$ of $(1.29 \pm 0.18)$ $\times 10^{7}\left(\mathrm{~mol} \mathrm{~L}^{-1}\right)^{-1}$. In contrast, $\mathrm{CRP}_{E \text {. coli }}$ bound to cAMP with a much lower association constant of $(2.3 \pm 0.22) \times 10^{5}$ $\left.(\text { mol L })^{-1}\right)^{-1}$ (Figure 3(c)), which was similar with the data previously reported $[8,25]$. These results indicated that $\mathrm{CRP}_{P \text {. putida }}$ was much more sensitive to cAMP signal than $\mathrm{CRP}_{\text {E. coli, }}$ which was consistent with the observation in the in vivo assay above.

Since cGMP could induce the activity of $\mathrm{CRP}_{P \text {. putida }}$ in the in vivo assay above, the binding stoichiometry and affinity of CRP proteins to cGMP was determined by in vitro ITC analysis as well. As shown in Figure 3(b), the interaction between $\mathrm{CRP}_{P \text {. putida }}$ and cGMP fitted one-site binding model and the association constant was $(1.01 \pm 0.06) \times 10^{5}$ $\left(\mathrm{mol} \mathrm{L}^{-1}\right)^{-1}$, 100 times lower than the interaction between $\mathrm{CRP}_{P \text {. putida }}$ and cAMP. The association constant of $\mathrm{CRP}_{\text {E. coli }}$ and cGMP was $(1.77 \pm 0.13) \times 10^{4}\left(\mathrm{~mol} \mathrm{~L}^{-1}\right)^{-1}$ (Figure $\left.3(\mathrm{~d})\right)$. Taken in vitro and in vivo assay data together, cAMP, but not cGMP, was the preferable signal ligand for $\mathrm{CRP}_{P \text {. putida }}$ to conduct its biological function.

\subsection{Thr132 is crucial for both high cAMP affinity and cGMP binding of CRP $_{P \text {. putida }}$}

As a first step to identify the determinant residues that caused the distinct property of $\mathrm{CRP}_{P \text {. putida }}$, sequence alignment was made to compare the differences between $\mathrm{CRP}_{P \text {. putida }}$ and $\mathrm{CRP}_{\text {E. coli }}$, particularly around the positions involved in direct cAMP or DNA binding (Figure 4). Two major dissimilarities were found in these two proteins: (i) $\mathrm{CRP}_{P}$. putida 
Table 2 ITC isothermal parameters of $\mathrm{CRP}_{P \text {. putida }}, \mathrm{CRP}_{P \text {. putida }} \mathrm{T} 132 \mathrm{~S}$ and $\mathrm{CRP}_{P \text {. putida }}$ Iex binding to cAMP or cGMP

\begin{tabular}{lccccc}
\hline & Ligand & $N^{\mathrm{a}}$ & $K_{\mathrm{a}}\left(\left(\mathrm{mol} \mathrm{L}^{-1}\right)^{-1}\right)$ & $\Delta \mathrm{H}\left(\mathrm{cal} \mathrm{mol}^{-1}\right)$ & $\Delta \mathrm{S} \mathrm{cal} \mathrm{mol}^{-1} \mathrm{deg}^{-1}$ \\
\hline $\mathrm{CRP}_{\text {P. putida }}$ & cAMP & $0.826 \pm 0.002$ & $(1.29 \pm 0.18) \times 10^{7}$ & $-2886 \pm 12.45$ & 22.9 \\
$\mathrm{CRP}_{\text {P. putida }}$ T132S & cGMP & $0.845 \pm 0.006$ & $(1.01 \pm 0.06) \times 10^{5}$ & $-6226 \pm 63.42$ & 2.01 \\
& cAMP & $0.556 \pm 0.011$ & $(2.36 \pm 0.50) \times 10^{5}$ & $-3244 \pm 90.67$ & 13.7 \\
$\mathrm{CRP}_{\text {P. putida }}$ Iex & cGMP & $0.743 \pm 0.012$ & $(3.70 \pm 0.25) \times 10^{4}$ & $-4730 \pm 110.5$ & 5.04 \\
& cAMP & $0.709 \pm 0.004$ & $(2.69 \pm 1.02) \times 10^{7}$ & $-5192 \pm 63.19$ & 16.6 \\
& cGMP & $0.724 \pm 0.013$ & $(1.76 \pm 0.29) \times 10^{5}$ & $-6906 \pm 183.2$ & 0.832 \\
\hline
\end{tabular}

a) $N$ represents the number of ligand binding site on each protein calculated by ITC assay.
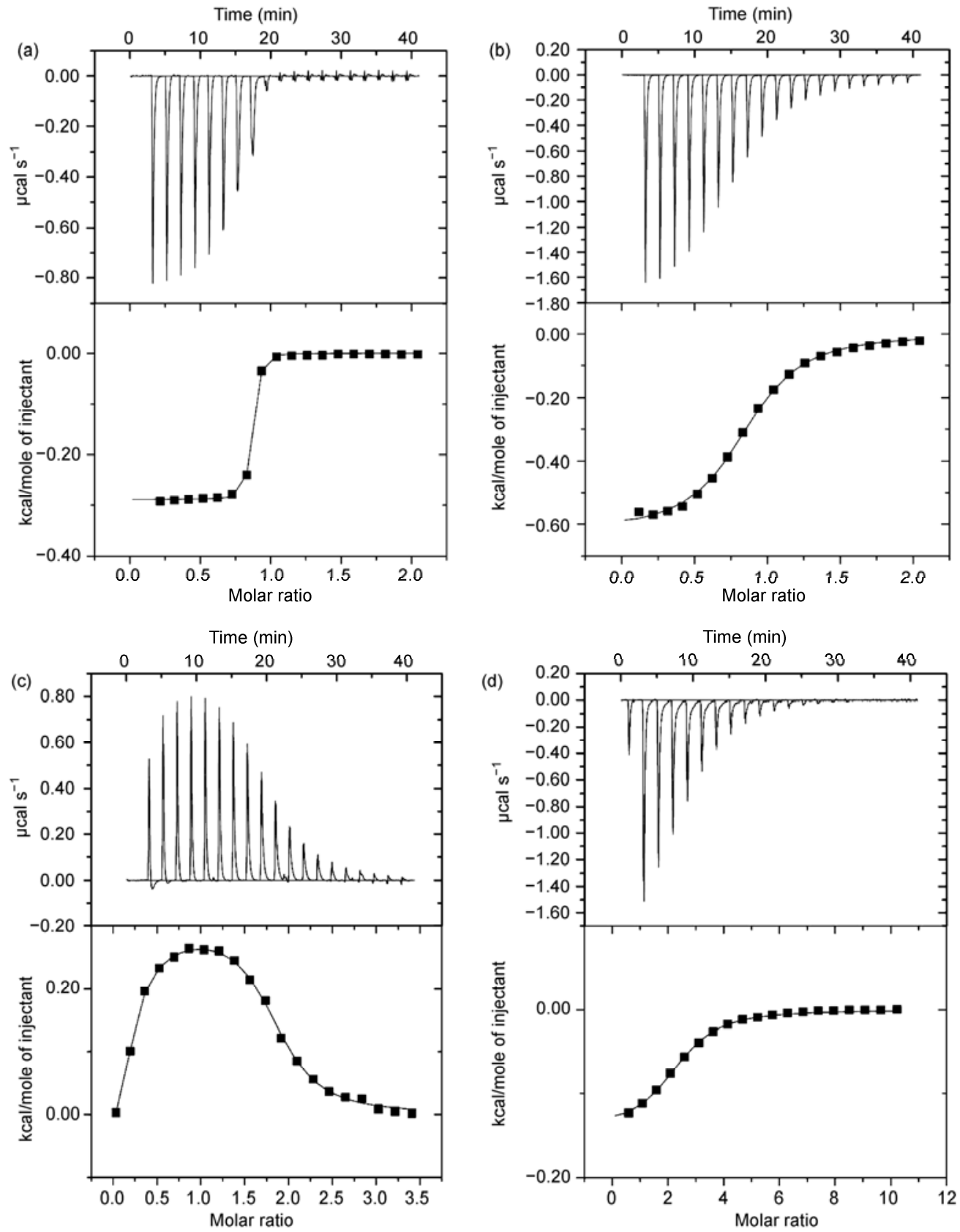

Figure 3 ITC analysis of cAMP and cGMP binding to $\mathrm{CRP}_{E \text { coli }}$ or $\mathrm{CRP}_{P \text { p putida. }}$ (a) ITC assay of $0.2 \mathrm{mmol} \mathrm{L}^{-1} \mathrm{CRP}_{P \text { putida }}$ with $2 \mathrm{mmol} \mathrm{L}^{-1} \mathrm{cAMP}^{-1}$ in Tris buffer; (b) $0.2 \mathrm{mmol} \mathrm{L}^{-1} \mathrm{CRP}_{\text {P. putida }}$ with $2 \mathrm{mmol} \mathrm{L}{ }^{-1}$ cGMP; (c) $0.1 \mathrm{mmol} \mathrm{L}^{-1} \mathrm{CRP}_{\text {E. coli }}$ with $2 \mathrm{mmol} \mathrm{L}^{-1}$ cAMP; (d) $0.2 \mathrm{mmol} \mathrm{L}^{-1} \mathrm{CRP}_{E \text {. coli }}$ with $10 \mathrm{mmol} \mathrm{L}^{-1}$ cGMP. Data from (a), (b) and (d) are best fitted with one-site binding model, data from (c) are best fitted with two-site binding model. 
contained three more residues (Pro79, Val80 and Glu83) in the cAMP binding pocket region; (ii) Thr132 of $\mathrm{CRP}_{P \text {. putida }}$ was replaced by Ser at the corresponding position of 128 in $\mathrm{CRP}_{\text {E. coli }}$. In order to verify the contribution of these residues, site-directed mutagenesis was carried out and the resulting mutant protein was subjected to ITC analysis. As shown in Figure 5(c), (d) and Table 2, deletion of the three additional residues (designated as $\mathrm{CRP}_{P \text {. putida }}$ Iex) had no influence on the ligand responsiveness. In contrast, the $\mathrm{CRP}_{P \text {. putida }} \mathrm{T} 132 \mathrm{~S}$ mutant showed incredible low cAMP affinity, almost two orders of magnitude's decrease (Figure 5(a), Table 2); The cGMP association constant of $\mathrm{CRP}_{P \text {. putida }}$ T132S dropped to the level below the physiological significance (Figure 5(b), Table 2). Both constants above were almost the same as $\mathrm{CRP}_{\text {E. coli }}$, which was $(2.3 \pm 0.22) \times 10^{5}$ or $\left.(1.77 \pm 0.13) \times 10^{4}(\mathrm{~mol} \mathrm{~L})^{-1}\right)^{-1}$ in the control experiments with cAMP or cGMP, respectively (Figure 3(c) and (d)). In consistence with in vitro assay, when $\mathrm{CRP}_{P \text {. putida }} \mathrm{T} 132 \mathrm{~S}$ was introduced into the cya crp double mutant $E$. coli strain, the lac promoter activity remained at very low level along with titrated exogenous cAMP and exhibited unresponsiveness to cGMP (Figures 1(a) and 2). All these data above suggested that the ligand binding properties of $\mathrm{CRP}_{P \text {. putida }} \mathrm{T} 132 \mathrm{~S}$ were nearly identical to those of $\mathrm{CRP}_{E \text {. coli }}$ [25], and the residue Thr132 was the key factor that influence the ligand binding properties of $\mathrm{CRP}_{P \text {. putida }}$.

\section{Discussion}

In this study, we demonstrated that CRP proteins from $P$. putida possess versatile ligand binding properties. $\mathrm{CRP}_{P \text {. putida }}$ has almost 100-fold higher cAMP affinity than $\mathrm{CRP}_{E \text {. coli }}$. This implies that $\mathrm{CRP}_{P \text {. putida }}$ requires less intracellular cAMP than $\mathrm{CRP}_{\text {E. coli }}$ to maintain its function. It is reported that unlike $E$. coli, in which the intracellular cAMP concentration fluctuates dramatically [27], cAMP level in Pseudomonas stays extremely low and stable [28,29]. This phenomenon might due to the weak adenylate cyclase activity
[14] or the effect of more than one active phosphodiesterases in Pseudomonas [30]. Therefore, the ligand binding affinity of $\mathrm{CRP}_{P \text {. putida }}$ may adapt to much lower concentration of intracellular cAMP.

The question about how many ligand binding sites are present in one CRP subunit has not been completely determined to date $[25,31,32]$. In any case, it is evident that large cAMP-induced conformational change is required for $\mathrm{CRP}_{\text {E. coli }}$ 's binding to target DNA site [33]. The structural modeling of $\mathrm{CRP}_{P \text {. putida }}$ using $\mathrm{CRP}_{E \text {. coli }}$ as template indicates slight structural difference between these proteins within the cAMP and DNA binding domain. Our observations based on the proteolytic digestion pattern of $\mathrm{CRP}_{P}$. putida with or without ligand suggest that $\mathrm{CRP}_{P \text {. putida }}$ undergoes a conformational transition upon cAMP binding. It is probably that similar conformational change (just like $\mathrm{CRP}_{\text {E. coli }}$ ) occurs to cAMP-bound $\mathrm{CRP}_{P \text {. putida }}$, which dramatically facilitates the protein-DNA interaction. Anyhow, it is evident that $\mathrm{CRP}_{P \text {. putida }}$ displays higher affinity with cAMP in one-site model in vitro and activates promoter activity in vivo in the presence of cAMP.

The responsiveness of $\mathrm{CRP}_{P \text {. putida }}$ towards cGMP is intriguing as well. As discussed above, cGMP could trigger

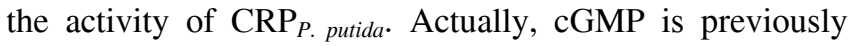
considered to be capable of activate VFR, a CRP homolog in Pseudomonas aeruginosa [34]. Recent work argues that cGMP is unlikely to play a biological role in VFR binding [35]. Consequently, we believe the situation should be the same in $\mathrm{CRP}_{P \text {. putida, as conditions containing such a high }}$ cGMP concentration can hardly be found in the environment. The capability of binding cGMP is probably a by-product of $\mathrm{CRP}_{P \text {. putida }}$ 's evolutionary shift to high cAMP affinity. Another consequence of this shift would be the presence of $\mathrm{CRP}_{P \text {. putida }}$ activity in the absence of cNMP (Figures 1(a) and 2). The similar property is also discovered in VFR, which regulated the las $R$ promoter through cAMPdependent and -independent mechanisms [35].

While the manuscript was submitted, a paper was published ahead online and showed that a MBP-CRP P. putida

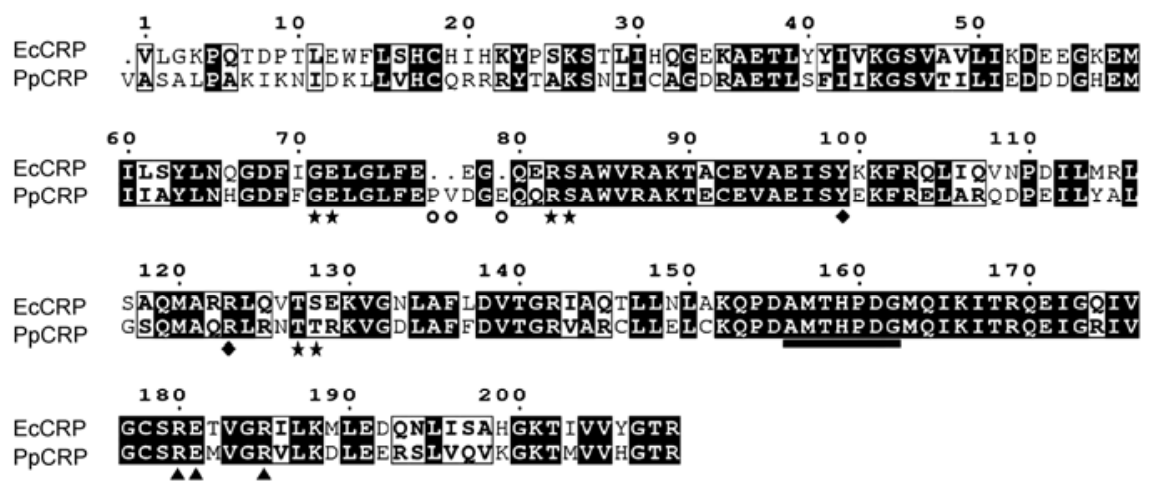

Figure 4 Sequence alignment of CRP protein from E. coli and P. putida. Star, residues participated in cAMP binding [2]; diamond, residues involved in stabilizing the cAMP binding pocket [2]; triangle, residues which directly contact with nucleotides in the binding site [26]; underlined, residues participated

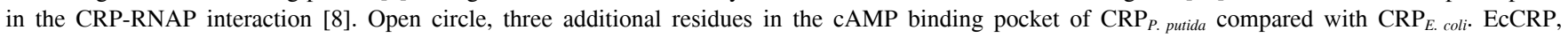
$\mathrm{CRP}_{\text {E. coli }}$; PpCRP, $\mathrm{CRP}_{\text {P. putida }}$. 

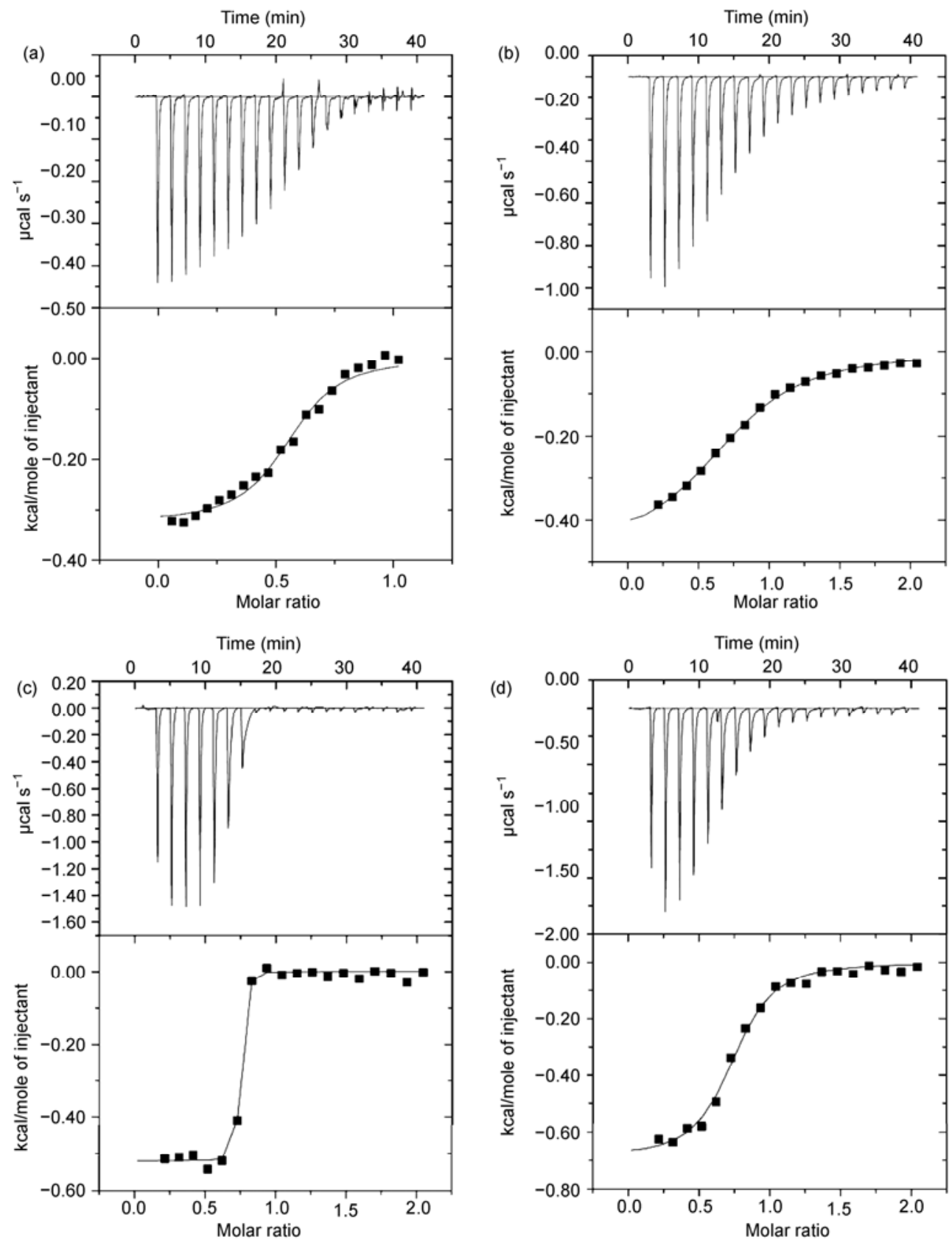

Figure 5 ITC analysis of cAMP and cGMP binding to $\mathrm{CRP}_{P \text { p putida }}$ mutants. (a) $0.2 \mathrm{mmol} \mathrm{L}^{-1} \mathrm{CRP}_{P \text {, putida }}$ T132S with $1 \mathrm{mmol} \mathrm{L}^{-1}$ cAMP; (b) $0.2 \mathrm{mmol} \mathrm{L}^{-1}$ $\mathrm{CRP}_{P \text {. putida }}$ T132S with $2 \mathrm{mmol} \mathrm{L}^{-1}$ cGMP; (c) $0.2 \mathrm{mmol} \mathrm{L}^{-1} \mathrm{CRP}_{P \text {. putida }}$ Iex with $2 \mathrm{mmol} \mathrm{L}^{-1}$ cAMP; (d) $0.2 \mathrm{mmol} \mathrm{L}^{-1} \mathrm{CRP}_{P \text {. putida }}$ Iex with $2 \mathrm{mmol} \mathrm{L}^{-1}$ cGMP. All data are best fitted with one-site binding model.

fusion protein possesses high binding affinity for cAMP in vitro [36]. In addition to confirming the $\mathrm{CRP}_{P \text {. putida's ultra- }}$ high cAMP responsiveness, this work has demonstrated the role of a key residue associated with ligand binding and promoter activation. The results obtained from the $\mathrm{CRP}_{P \text {. putida }}$ T132S mutant reveal that the Thr132 residue is responsible for all the signal sensing properties discussed above. Previous work has proved that the S128T mutation of $\mathrm{CRP}_{E \text {. coli }}$ at the equivalent position could make the protein sensitive to cGMP without changing the cAMP binding affinity [37]. It might be speculated that the Thr132 residue has altered $\mathrm{CRP}_{P .}$ putida's cAMP binding pocket a better space structure to accommodate cGMP for activation. The substitution of Thr132 to Ser should have caused somewhat modest conformational change, because of which remarkable loss of cAMP and cGMP affinities are taken place. Our preliminary data with multiple sequence alignments show that in genus Pseudomonas, nearly $90 \%$ residues at the position 132 are Thr; whereas in Enterobacteria, 90\% remain Ser at this equivalent site. These interesting observations might be coincidental to meet the reality that the distinct ligand binding properties of CRP proteins originate from the 
diverse amino acid residues at this position. In conclusion, $\mathrm{CRP}_{P \text {. putida }}$ demonstrates a high level of cAMP affinity, and Thr132 residue of $\mathrm{CRP}_{P \text {. putida }}$ plays important role in such ligand binding properties. A detailed study is expected to understand the reason of why it needs such unusual signal sensing properties.

We are grateful to Profs. V. de Lorenzo and J. L. Ramos for P. putida strains and plasmids. This work was supported by the National Basic Research Program of China (2010CB126503), and the National Natural Science Foundation of China (30830005 and 39925017).

1 Kolb A, Busby S, Buc H, et al. Transcriptional regulation by cAMP and its receptor protein. Annu Rev Biochem, 1993, 62: 749-795

2 West S E, Sample A K, Runyen-Janecky L J. The $v f r$ gene product, required for Pseudomonas aeruginosa exotoxin A and protease production, belongs to the cyclic AMP receptor protein family. J Bacteriol, 1994, 176: 7532-7542

3 Korner H, Sofia H J, Zumft W G. Phylogeny of the bacterial superfamily of Crp-Fnr transcription regulators: Exploiting the metabolic spectrum by controlling alternative gene programs. FEMS Microbiol Rev, 2003, 27: 559-592

4 Mao X J, Huo Y X, Buck M, et al. Interplay between CRP-cAMP and PII-Ntr systems forms novel regulatory network between carbon metabolism and nitrogen assimilation in Escherichia coli. Nucleic Acids Res, 2007, 35: 1432-1440

5 Grainger D C, Hurd D, Harrison M, et al. Studies of the distribution of Escherichia coli cAMP-receptor protein and RNA polymerase along the E. coli chromosome. Proc Natl Acad Sci USA, 2005, 102: 17693-17698

6 Ptashne M, Gann A. Transcriptional activation by recruitment. Nature, 1997, 386: 569-577

7 Passner J M, Steitz T A. The structure of a CAP-DNA complex having two cAMP molecules bound to each monomer. Proc Natl Acad Sci USA, 1997, 94: 2843-2847

8 Harman J G. Allosteric regulation of the cAMP receptor protein. Biochim Biophys Acta, 2001, 1547: 1-17

9 De Crombrugghe B, Busby S, Buc H. Cyclic AMP receptor protein: Role in transcription activation. Science, 1984, 224: 831-838

10 Busby S, West D, Lawes M, et al. Transcription activation by the Escherichia coli cyclic AMP receptor protein. Receptors bound in tandem at promoters can interact synergistically. J Mol Biol, 1994, 241: 341-352

11 Tian Z X, Li Q S, Buck M, et al. The CRP-cAMP complex and downregulation of the $g \ln A \mathrm{p} 2$ promoter provides a novel regulatory linkage between carbon metabolism and nitrogen assimilation in Escherichia coli. Mol Microbiol, 2001, 41: 911-924

12 Popovych N, Tzeng S R, Tonelli M, et al. Structural basis for cAMP-mediated allosteric control of the catabolite activator protein. Proc Natl Acad Sci USA, 2009, 106: 6927-6932

13 Weinel C, Nelson K E, Tummler B. Global features of the Pseudomonas putida KT2440 genome sequence. Environ Microbiol, 2002, 4: 809-818

14 Milanesio P, Arce-Rodriguez A, Munoz A, et al. Regulatory exaptation of the catabolite repression protein (Crp)-cAMP system in Pseudomonas putida. Environ Microbiol, 2011, 13: 324-339

15 Daniels C, Godoy P, Duque E, et al. Global regulation of food supply by Pseudomonas putida DOT-T1E. J Bacteriol, 2010, 192: 2169-2181

16 Linder J U. cGMP production in bacteria. Mol Cell Biochem, 2010, 334: 215-219

17 Leduc J L, Roberts G P. Cyclic di-GMP allosterically inhibits the CRP-like protein (Clp) of Xanthomonas axonopodis pv. citri. J
Bacteriol, 2009, 191: 7121-7122

18 Tao F, He Y W, Wu D H, et al. The cyclic nucleotide monophosphate domain of Xanthomonas campestris global regulator Clp defines a new class of cyclic di-GMP effectors. J Bacteriol, 2010, 192: 10201029

19 Marden J N, Dong Q, Roychowdhury S, et al. Cyclic GMP controls Rhodospirillum centenum cyst development. Mol Microbiol, 2011, 79: 600-615

20 Baba T, Ara T, Hasegawa M, et al. Construction of Escherichia coli K-12 in-frame, single-gene knockout mutants: The Keio collection. Mol Syst Biol, 2006, 2: 2006-2008

21 Nakazawa T. Travels of a Pseudomonas, from Japan around the world. Environ Microbiol, 2002, 4: 782-786

22 Li Y, Sun Y C, Yan H Q, et al. Alternative split sites for fragment complementation, and glyphosate function as extra ligand and stabilizer for the AroA enzyme complexes. Chin Sci Bull, 2011, 56: 514-520

23 Sambrook J, Russell D. Molecular Cloning: A Laboratory Manual. 3rd ed. Cold Spring Harbor: Cold Spring Harbor Laboratory Press, 2001

24 Miller J H. Experiments in Molecular Genetics. New York: Cold Spring Harbor Laboratory Press, 1972

25 Gorshkova I, Moore J L, Mckenney K H, et al. Thermodynamics of cyclic nucleotide binding to the cAMP receptor protein and its T127L mutant. J Biol Chem, 1995, 270: 21679-21683

26 Parkinson G, Wilson C, Gunasekera A, et al. Structure of the CAPDNA complex at 2.5 angstroms resolution: A complete picture of the protein-DNA interface. J Mol Biol, 1996, 260: 395-408

27 Hogema B M, Arents J C, Inada T, et al. Catabolite repression by glucose 6-phosphate, gluconate and lactose in Escherichia coli. Mol Microbiol, 1997, 24: 857-867

28 Siegel L S, Hylemon P B, Phibbs P V Jr. Cyclic adenosine 3',5'monophosphate levels and activities of adenylate cyclase and cyclic adenosine 3',5'-monophosphate phosphodiesterase in Pseudomonas and Bacteroides. J Bacteriol, 1977, 129: 87-96

29 Phillips A T, Mulfinger L M. Cyclic adenosine 3',5'-monophosphate levels in Pseudomonas putida and Pseudomonas aeruginosa during induction and carbon catabolite repression of histidase synthesis. J Bacteriol, 1981, 145: 1286-1292

30 Fuchs E L, Brutinel E D, Klem E R, et al. In vitro and in vivo characterization of the Pseudomonas aeruginosa cyclic AMP (cAMP) phosphodiesterase CpdA, required for cAMP homeostasis and virulence factor regulation. J Bacteriol, 2010, 192: 2779-2790

31 Weber I T, Steitz T A. Structure of a complex of catabolite gene activator protein and cyclic AMP refined at $2.5 \AA$ resolution. J Mol Biol, 1987, 198: 311-326

32 Lin S H, Lee J C. Communications between the high-affinity cyclic nucleotide binding sites in E. coli cyclic AMP receptor protein: Effect of single site mutations. Biochemistry, 2002, 41: 11857-11867

33 Sharma H, Yu S, Kong J, et al. Structure of apo-CAP reveals that large conformational changes are necessary for DNA binding. Proc Natl Acad Sci USA, 2009, 106: 16604-16609

34 Beatson S A, Whitchurch C B, Sargent J L, et al. Differential regulation of twitching motility and elastase production by $\mathrm{Vfr}$ in Pseudomonas aeruginosa. J Bacteriol, 2002, 184: 3605-3613

35 Fuchs E L, Brutinel E D, Jones A K, et al. The Pseudomonas aeruginosa $\mathrm{Vfr}$ regulator controls global virulence factor expression through cyclic AMP-dependent and -independent mechanisms. J Bacteriol, 2010, 192: 3553-3564

36 Arce-Rodriguez A, Durante-Rodriguez G, Platero R, et al. The Crp regulator of Pseudomonas putida: Evidence of an unusually high affinity for its physiological effector, cAMP. Environ Microbiol, 2012, 14: 702-713

37 Lee E J, Glasgow J, Leu S F, et al. Mutagenesis of the cyclic AMP receptor protein of Escherichia coli: Targeting positions 83, 127 and 128 of the cyclic nucleotide binding pocket. Nucleic Acids Res, 1994, 22: 2894-2901

Open Access This article is distributed under the terms of the Creative Commons Attribution License which permits any use, distribution, and reproduction in any medium, provided the original author(s) and source are credited. 